\title{
Space, place and ecology: Doing ecofeminist urban theology in Gauteng
}

\begin{abstract}
Author:
Annalet van Schalkwyk ${ }^{1}$

Affiliation:

${ }^{1}$ Department of Christian Spirituality, Church History and Missiology, University of South Africa, South Africa

\section{Note:}

This article forms part of the special collection on 'Doing urban public theology in South Africa: Visions, approaches, themes and practices towards a new agenda' in HTS Teologiese Studies/Theological Studies Volume 70, Issue 3, 2014. The collection is the result of the project 'Urban Public Theology', which was initiated by the Institute for Urban Ministry but later expanded to include several academic departments and institutes at the University of Pretoria (UP) and University of South Africa (UNISA). The leading centres in this regard were the Centre for Contextual Ministry (UP) and the Research Institute for Theology and Religion (UNISA)
\end{abstract}

Correspondence to: Annalet van Schalkwyk

Email:

vschaa@unisa.ac.za

\section{Postal address:}

PO Box 392, University of South Africa, Pretoria 0003, South Africa

\section{Dates:}

Received: 17 June 2014 Accepted: 26 July 2014

Published: 20 Nov. 2014

\section{Read online:}

The basic motivation for this article is to explore the critical, yet hopeful vision which urban theologians - and specifically ecofeminist urban theologians - have for justice, reconciliation and abundance of life in urban Gauteng. This requires that urban spatiality, with its conflicting sides in a rampantly capitalist Gauteng, needs to be understood. It also requires an understanding of how urbanity and ecology may - yet so often do not - overlap. According to ecofeminist theologian Anne Primavesi, space and place needs to be understood in relation to the earth as the body of God - a web of interrelated and interconnected subjects and living beings which constitute the earth with its various ecosystems. This belies the established understanding that space and place is created mostly through the anthropocentric activity and mastery of people. Such an ecological understanding of space, place and urbanity leads to my exploration of a missiology of space as the manifestation of the presence of God in the spaces of nature and human civilisation. I conclude by proposing the practice of urban mission as making the liturgical and sacramental links between ecology, space, and the reclamation of urban space as sacred by Christian and other agents of urban activism.

\section{Introduction}

In this article I will explore space and place, displacement of people and nature in an urban context, from an ecofeminist theological point of view. I will specifically work with these themes within the urban context of Gauteng of 2014.

I will deal with the questions of how one understands the spatiality of an urban context as part of the greater ecology; and how urban development and capitalism displaces not only the natural spaces and resources of the ecology, but also poor and marginalised human communities and individuals.

My basic motivation for this exploration is to find a critical yet creative vision of hope which public urban theologians and practitioners - and specifically those like myself who work from an ecofeminist theological perspective - may develop, for the growing Gauteng metropole but also for other South African cities.

What is the basic ecofeminist critique that we bring into a teleological reading of the city? What is the vision of creativity and hope which we bring into dialectic tension with the realities of the city? What practical approaches do we propose to bring about recreation, redemption and hope to the city in an apocalyptic time of ecological crises and global warming? How do we see the greening power of the Spirit - to quote Hildegard of Bingen (see Bowie \& Davies 1990) - working in and through us, through communities, through the processes of the ecology, even though the oppressive and destructive forces at work in cities, so as to bring about a sustainable future for our cities, our country and our planet?

How does ecofeminist theology assist urban theologians and practitioners - or missionaries - to understand the scope of the missio Dei and God's work of creation, salvation and restoration in and around the city? How does ecofeminist theology assist Christian searchers to understand the missio Dei, not as human action on behalf of God, but as participation in the Spirit's movement towards a fresh embodiment of Christ's mission in communion with Creation (Conradie 2011)? How may an interaction between an ecofeminist critique of society, and a reflection on urbanity and ecology contribute towards such a renewed understanding of the missio Dei and of the movement of the Spirit of God, society and ecology? How does such an ecofeminist theological exploration contribute towards urban ministry and urban activism of Christian practitioners and other civil society agents in the cities of Gauteng?

At the heart of my search is my belief that the loving outreach of God's heart or the missio Dei is intrinsically present in and around creation, in recreation and also in human civilisation. This

How to cite this article: Van Schalkwyk, A., 2014, 'Space, place and ecology: Doing ecofeminist urban theology in Gauteng', HTS Teologiese Studies/Theological Studies 70(3), Art. \#2767, 13 pages. http://dx.doi.org/10.4102/hts.v70i3.2767

Copyright: @ 2014. The Authors. Licensee: AOSIS OpenJournals. This work is licensed under the Creative Commons Attribution License. 
belief resonates with the views of ecofeminist theologian Sallie McFague (1993:19-20) that the earth is the body of God, which God carries lovingly in Godself. This love, in a panentheistic manner, brought forth life, holds life together and evolves with the whole cosmos into what will be the new heaven and new earth of Revelation 21. Here, the city of Jerusalem is the place where God dwells, the sign of God's presence, the place where humanity will be finally redeemed and where humankind finds peace in and on the earth. This creative and redemptive mission of God is among us in its affirmative 'Yes' of the goodness of life; but also in the warnings and judgements, the ' $\mathrm{No}^{\prime}$, that we need to heed if we want to move towards a future which may be a sustainable 'home for all' for humanity in harmony with ecology.

My thesis is that an exploration of this creative and redemptive mission may bring about the restoration of the ecology of life - urban, human, natural, Bankenveld - the restoration of the whole earth ecosystem. It may bring about new and innovative, sustainable ways of living in an earthly city where the 'greening power of the spirit' brings the fullness of life to the most marginalised communities; and life-sustaining justice to the centres of innovation, economy, and political power of the city, in an egalitarian and participatory manner. Part of this vision of the restoration and renewal of the ecology of life in the cities of Gauteng is the overhaul and transformation of the hierarchical and patriarchal systems which oppress and destroy the lives of women, children, the youth, the marginalised and the ecology; so as to open up possibilities for 'power with' and 'power through' systems of society and ecology to flourish to the full in urban processes, places and spaces.

\section{A process theological understanding of the urban spatiality of Gauteng}

Process thinkers see the world as composed entirely of events of subjective experiences of physical elements, living organisms and humans, and of the interactions between these. The experiences of these elements and organisms are fundamentally relational, coming into existence anew in every moment, and evolving out of its past (Mesle 1993:54-55). This leads some process theologians to say that God is an actual process, operative within the subjective experiences and interactions in and between nature and humanity (Cobb 2007:165-169). Such a process understanding of the Sacred and of reality is coherent with the thought of ecofeminist theologians, who work from their specific locations and experiences as women within the dynamic flow and interaction of matter and energy, organisms and ecology, social processes and discourses through time and space (Howell 2011:20-28). This process theological approach is appropriate to use in an exploration not only of the geological evolving of the rock layers in the Witwatersrand area, as this is part of the larger ecological and eventually historical processes which brought to us the Gauteng that we know in 2014, but also of the continuing presence of God in the spatiality of Gauteng as manifested through the agency of natural process and human action.
Join me in an exploration of this unfolding process of urban spatiality. Join me in a bird's flight over Gauteng, and explore with me the sights and textures of a rampantly growing metropole, situated in the age-old quartzite ridges and shale valleys of the Witwatersrand and Magaliesberg. Imagine the rocks underneath the surface of Johannesburg and the East and West Rand where gold deposits are mined and brought to the surface through extended systems of shafts and tunnels. Follow the rivers and underground aquifers which flow through Gauteng and see how the water systems are affected by human settlements' pollution and discharges from mines and industry. See how suburbs, city centres, business areas, mines and mine dumps, townships, rapidly developing new settlements, squatter areas and rapidly developing road systems fit into, but mostly superimpose themselves on the grassland, Bankenveld and bushveld biomes. Travel with me through the past and present history of human settlement and activity in Gauteng: the evolvement of prehistoric humanity in what is now called the Cradle of Humankind, early Bantu and then Nguni- and Sotho-speaking tribes migrating through the area and settling in various places; Voortrekkers moving in from the South and establishing Pretoria, then the discovery of gold and diamonds and the flood of 'outlanders' into the Witwatersrand area and the establishment of the sprawling mining town, Johannesburg; the establishment of mines and industries, the growth of suburbs and shanty towns, the dynamic interactions of people from various countries, backgrounds, cultures and races; the growth of education and health systems and the burgeoning of religious communities of various kinds, the evolvement of various phases of white political supremacy and black subservience which affects black populations in rural areas and neighbouring countries; the struggle of black people to re-establish their rightful place in this rich area of South Africa; the coming of a new democratic era; the growth of a rampantly capitalist economic system based on mining, industry, global and local trade, agriculture and the sourcing of water and electricity from other parts of the country and sub-continent.

\section{Gauteng: Some facts and statistics}

According to the 2011 census results the province of Gauteng is the place of residence of 12272264 people. Johannesburg is the historic centre of the mining industry and is the financial and business powerhouse of the country. It is also the provincial capital of Gauteng. Various municipalities in Gauteng accommodate many local and small businesses and industries. To the south of the province, Vereeniging and Vanderbijlpark are the industrial centre for Sasol and the diesel manufacturing industry (Statistics SA n.d). Although the discovery of gold, diamonds and coal led to the tremendous economic growth and the urbanisation of what became Gauteng, this is no longer the case. The mining industry is still active, but it is in decline and its contribution to the economic growth of Gauteng is becoming less - especially in the western municipalities such as Mogale City and Merafong District. On the other hand, the gross domestic product (GDP) growth in Johannesburg and Ekhurhuleni is growing as a result of business and manufacturing activities (Statistics SA n.d.). Gauteng is also 
the 'Cradle of Humankind' where paleontological discoveries of prehistoric human remains were found.

The legacy of white rule and apartheid economic, social and spatial engineering still dominates the province despite the national, provincial and local democratic governments' concerted efforts to turn this around. Predominantly black townships are to be found on the outskirts of what were the white city centres and suburbs of cities that were built for white privilege, wealth and ownership of the driving engines of the economy. The early mining industry drew predominantly black men from rural areas to become the labour force on which the mining industry was built. The notorious pass system and group areas act ruled the movement of black labour and the settlement of black people in townships around the major cities in Gauteng. Under apartheid, black people were moved into peri-urban Bantustan settlements to the north and west of Pretoria. Democracy made it possible for black people to move to city centres and neighbourhoods, closer to the economic hub of the province. But, again, new spatial divides between rich and poor emerged with the 'flight' of white people out of city centres (Murray 2011:87) and the unfettered urban sprawl and development of new business centres and security estates for the middle and upper classes. At least, the national, provincial and municipal governments are developing some successful new urban settlements for the lower middle classes and the poor, such as Cosmo City and Olievenhoutbosch. Another demographic feature of the province is the influx of many rural people as well as 'foreign nationals' from other African countries, who come here in search of the wealth and employment that Gauteng (meaning 'The Place of Gold') supposedly offers. They quite often end up living in city centres from which capital and business have, to a large extent, fled or in squatter camps - often in-between townships and richer neighbourhoods or on the outskirts of such areas.

\section{An ecofeminist and systems understanding of the relationship between space, place and the body of God}

How does one understand the concepts 'space' and 'place' in this flux of natural and human reality which gave form to the Gauteng metropole? I can only concur with Tuan's (1977:3-7) simple yet timeless explanation: space requires movement from a place to another place. Similarly, a place requires a space to be a place. Hence, the two notions are co-dependent. He also relates space to having temporal insinuations and places having physical insinuations, which further clarifies the difference and co-dependency between the two concepts. I would add to this that space is multidimensional, while place is topical. For our exploration, it is important to understand the co-dependency of the two notions in the 'flow' of a process and ecological approach.

Our flight over Gauteng leads to a process and relational understanding of space, place and environment. Space and place cannot be divorced from its environment as it is formed by the processes of time, matter and energy, evolution and history. Moltmann (in Gorringe 2002:42) proposes an ecological concept of space in which every created reality has its own proper environment, its own inexistentia. Space exists, according to Aquinas, because God is in everything, in body, in space (Gorrindge 2002:42). Space and place can, furthermore, be explained in terms of Sallie McFague's (1993:40-47) understanding of the earth as the Body of God, as it is informed by the 'common creation story' of the evolving earth. This scientific 'story' is 'told' by scientists' new understandings and theories about the origins and the evolvement of earth and universe. The Body of God is the web of interrelated and interconnected subjects and living beings which constitute the earth with its various ecosystems. It is within this web that space and place is situated. Anne Primavesi (2000:135) reminds us that spaces and places are a reflection of the relationship between matter and energy, organism, activity and environment. No organism exists without an environment, no environment without an organism. Environments, spaces and places are forged through the processes of nature and the activities of living beings. In Primavesi's understanding, it is within the spaces embedded in evolving ecological systems that one needs to 'place' and to read the Christian narrative.

This ecofeminist and systemic understanding of space and places belies our established notion of space as created mostly through the activity and the mastery of people, as anthropocentric and as fixed. 'Space' does not merely refer to the spaces in 'man-made' and socially constructed built environments such as the cities of Gauteng - although this social understanding of space is not excluded here. In a process and ecological understanding of space and place in Gauteng, these two concepts, namely, 'space' and 'place' are both geologically and historically connected and interactive. In a concrete manner, the underground rock layers and surface topography of the Witwatersrand, which was formed over billions of years, defines the 'place' which became significant when gold was discovered in 1886. It is here that the 'spaces' of the early Johannesburg mining town were built by all the people who streamed to Place of Gold - gold diggers, labourers, rich investors, merchants, prostitutes. There is enough reason to observe cynically that the Johannesburg of 2014 is still a rampantly growing mining town. Of course, the early Nguni- and Sotho-speaking tribes found in the ridges, valleys and grasslands of what became Gauteng the place for constructing their significant spaces, their villages and kraals for themselves and their cattle, places to bury and revere their ancestors, and shelter against enemy tribes. The Voortrekkers found in the Fountains Valley a lovely place to 'outspan', to make a living from the bounty of nature and eventually to build Pretoria, their own capital and their own space, around 1840. The interaction and conflict between black tribes, Voortrekkers and 'outlanders' and the ensuing history of what became Gauteng happened spatially and interactively with the geography and topography of this region. Human spacemaking and claiming of place plays out in interaction with the body of the ecology, the Body of God, which holds place and space together. What was interaction between human space 
and activity and ecology eventually became an exploitative relationship between human spatial settlement and ecology. Yet, the relationships between matter and energy, organisms, activities and ecology in the Body of God continue to unfold in the evolvement of human and natural history.

McFague (1993:102, 180-181) goes further to say that Christian theology has not traditionally been concerned with, or interested in spatial matters; but it is precisely time and space, as the new cosmology and new physics remind us, that must now enter our consciousness so that we can make sense of our particular setting, our place, on this earth, in the province of Gauteng, within the body of the Cosmic Christ. Salvation, therefore has to be understood as spatial - salvation occurs in specific spaces and locations within creation. For our topic, salvation happens in specific spaces within the Gauteng metropole.

How do we understand city, and urban space, within an ecological and systemic ontology of space and place? And what does this mean for what can be either a limited or a comprehensive understanding of God's salvation within an urban context?

\section{The dialectics of the city}

Tim Gorringe (2002:140) speaks about the dialectics of the city. This is reflected in the deep ambivalence towards the city in the Christian tradition.

\section{Civitas and oikos}

On the one side, 'city' is a place of civilisation, of civitas, human endeavour, creativity and culture, the dynamic meeting place of people. It can be a place of rich and deep humanity which may bring together different communities of people. It is the paradigm of the human home, of the dwelling place, where human beings can come home when they experience their environment as meaningful. When this happens, space becomes place in the sense that space is filled with meaning. This sense of being placed, of coming from a specific and a very special dwelling place in a specific space and environment, is central to the human experience (Gorringe 2002:1). The oikos [home] theme in ecological and ecumenical theology is well-known. The city can be home, dwelling place, household, oikos, within the larger oikos of creation. The city of Jerusalem is the place where God dwells, the sign of God's presence, the place where humanity will be finally redeemed and where humankind finds peace (Gorringe 2002:140). A city can be a garden city, with parks and green open spaces, nature reserves and natural features, where humans can come home to nature, and where the ecology plays a role in place making.

\section{Babylon and Edge City}

On the other hand, the city is understood as a focus of violence and human hubris. We are reminded of Jesus' description of Jerusalem, the city of peace, as the city where the prophets are stoned (Lk 19:41). The city is also Babylon, the place of oppression, alienation, exile, estrangement and violence (Gorringe 2002:140). I will later re-interpret the name 'Babylon' and call it 'Edge City' and 'City of Extremes'. In our globalised world many cities are places of rampant capitalism where the market and consumerism reigns above all and where everyone - rich and poor - are trapped in the aspirations of consumerism and the accumulation of wealth. This is typical of Gauteng, the richest of all the South African provinces, where all of us - whether we are 'old rich', established white middle class, 'black diamonds', or youngsters with no chance of making it in the systems and who therefore resort to crime, are caught up in the capitalist dream of economic growth at all costs. The positive side of growth is the recognition of the need to provide the best possible standard of living for a society's people. The downside is that it invariably becomes an end in itself, a compulsion. This is what drives the urban and rural poor increasingly into the squatter settlements of cities. Above all, it alienates us from the planet, chokes her atmosphere and ravages her resources. It refuses to recognise the limits of the earth's resources and, as a result, threatens the livelihoods of hundreds of thousands of the world's poorest people through global warming, and it destroys the biodiversity and the ecosystems of the earth. This is savagery and sin on a scale which the earth has never seen before.

\section{Displaced nature and displaced people - Gauteng's case}

This brings me to the theme of displacement - the displacement of nature but also the displacement of people. Jacklyn Cock (2008:10-13) argues in her book, The war against ourselves: Nature, power and justice, that people in our globalised and urbanising world - and specifically in South Africa - are alienated from nature to such an extent that we do not realise that we depend on nature on a very basic level for all areas of our lives. Nature becomes hidden and displaced - especially in growing urban areas like Gauteng. We 'lobotomise' our brains to block any uncomfortable awareness about bodily wastes, or water consumption, or the killing of animals, because sewerage pipes run unseen underground and at least some of us can 'sanitise' our daily lives and not even think about that 'nasty' reality. Water is provided by Rand Water and we do not have to think about the costly water systems that link us to the Lesotho Highland Water Scheme, while many Lesotho citizens do not have the convenience to open a tap and to drink clean water - with the result that women have to walk long distances to fetch water. This same Scheme, of which the second phase was completed in 2002, was funded by the World Bank and other international investors. Their logic was to continue tapping the natural resources to build the infrastructure needed for the capitalist and profit-driven economic engine of Gauteng, thereby benefiting the lifestyle of middle- and upper classes, big businesses and industries, but not the poor in Lesotho and Gauteng. The development of this scheme took power 'over' the mountains, fragile grasslands systems, gorges and rivers of Lesotho, forgetting about the need for more access to water in the rural economy in Lesotho, 
displacing tens of thousands of Basotho peasants, inundating sacred land, threatening endangered species and endangering the Orange River's downstream ecosystem. At the time of the building of the Scheme, the grass roots protests in Lesotho, Alexandra and Soweto demanded that over-consuming water users in mines, factories and mansions should pay higher tariffs in relation to their water wastage. They also demanded that the access to water by Basotho subsistence farmers, as well as decent access to water and minimum tariffs for the poor in townships must be prioritised. These demands were not heard (Bond 2002:11-12). In recent years, service delivery protests in townships like Alexandra, Diepsloot and Bekkersdal and many other places are often about problems with the delivery of water to these communities, the inability of poor households to pay water tarrifs, and sewerage problems (Dlamini 2014; Grant 2014). Those in the middle classes do not even have to think about the water pollution in streams and rivers in Gauteng, which affect poor communities, such as the Jukskei River which runs through townships like Alexandra and Diepsloot and becomes badly polluted due to garbage and congested or non-existent sewerage systems. The irony is that the Jukskei eventually flows into the Hartebeespoort Dam, around which various luxury housing complexes and 'ecoestates' are being built at a fast pace.

Displacement and amnesia go together: we often forget that Gauteng's powerful economy was, and still is, based on mining and that mining has serious environmental consequences. When deep shaft mining on the Witwatersrand started in the early 1900s, people had no idea what impact mining would have on those hidden spaces and hidden water sources beneath the earth's surface as well as water systems and land on the surface. For example: the mining pollution of mines around Randfontein and Krugersdorp feeds into water systems like the Wonderfontein Spruit which again affects ecosystems, communities and agriculture all the way from Krugersdorp to Potchefstroom. In mining, gold is extracted from the ore, which is brought to the surface by literally 'rinsing' it with water and chemicals. The waste rock is what we typically see on mine dumps. The waste water, chemicals and crushed rock are 'stored' in tailings dams. Polluted water seeps out of the tailings dams and enters rivers and groundwater systems (Coetzee 2004; McCarthy 2011).

The City of Johannesburg is continuing to thrive economically whilst the pollution problems created by mining are literally displaced in another area towards the southwest of Johannesburg. Gauteng is located on a high-altitude watershed, which means that outflows of water waste from mines, industries and general usage pollute further downstream water resources as it flow into the Vaal River. Very expensive clean water from the upstream Vaal Dam and Lesotho Highland Scheme is then blended with polluted Vaal River water to dilute the pollution. Thus massive quantities of clean water are wasted in effect. In the meantime, to maintain the supply of good quality water for Gauteng, we depend on the Lesotho Highlands Water Scheme. The result is that after China, South Africa's water resources contain some of the highest toxin levels in the world. In short, the combination of low average rainfall, over-exploitation and re-engineered spatial flows have led South Africa to an imminent water crisis in quantity as well as quality (Swilling \& Annecke 2012: 234).

The same situation occurs with the mining of coal and the generating of electricity in Mpumalanga, which has disastrous environmental consequences for that area (WWFSA n.d.; Kardas-Nelson 2010), whilst Gauteng thrives on the electricity coming from what is literally a wasteland. The economic and political power of Gauteng is, literally and figuratively speaking, built upon these wastelands and tailings dams. Here, the entrenched power of the coal industry and the Eskom power stations displaces and destroys nature on a massive scale, whilst it exposes middle class and poor communities to pollution and environmental hazards.

The extreme level of the exploitation of natural resources in South Africa, such as coal, minerals and water, serves the vested interests of the old and new captains of industry. However, this approach to economic growth does not contribute to a real solution for our society's present problems with poverty. Government has shifted policy towards sustainable development as a solution to poverty and the depletion of resources through, for example, the National Framework for Sustainable Development of 2008, and the Integrated Resource Plan for Electricity and a Renewable Energy Feed-in Tariff for cleaner energy, which was introduced in 2009 (Swilling \& Annecke 2012:226-233). Despite this, the power block of the mineral and energy sector - in a country which relies heavily on carbonintensive energy and is bolstered by both foreign investment in this sector and large-scale mineral and coal export to emerging economies such as India and China- withholds the government from moving significantly towards a sustainable economy. In addition, big-scale investment in new coal mining in the Waterberg and the construction of two new coal-based electricity plants, namely Medupi and Kusile, to provide the country with dirty energy simply contributes to more ecological problems which translate into social problems (Swilling \& Annecke 2012: 226-233). Apart from polluting living conditions for thousands of people, this approach to economic growth and the generation of energy is also contributing to the changing climate patterns worldwide, but specifically in Southern Africa. These range from desertification on the Western side of the sub-continent to devastating storms and floods on the eastern side. This adversely affects the food production and livelihoods of poor rural communities all over Africa. The ecological footprint of Gauteng is becoming bigger and bigger - not only within neighbouring provinces, but also all over the world. South Africa, with its heavy dependence on coal-based electricity and on petrol-based transport and with its lack of measures to purify the emissions of industries and power stations - while the technology is already available - is the largest emitter of greenhouse gases on the African continent (Burck, Marten \& Bals 2014). And yet, we go on living as if the consequences do not matter. Ecological displacement and amnesia is at the order of the day. Ecological displacement is inextricably related to social displacement and poverty. At the core of the 
problem is our country's clinging to a capitalist, neo-liberal economic paradigm which serves the vested interests of a conglomerate of powerful people and industries, despite its professed commitment to the eradication of poverty (Bond 2002:xvi) and sustainable development (Swilling \& Anneke 2012:242-243). Power displaces nature and people.

\section{Displaced communities - Edge City and 'squatter camps'}

It is not only nature which is displaced and forgotten in big cities. It is also those who are marginalised by big capitalist developments and the lifestyles of the privileged.

In Gauteng's rampantly capitalist economy, people are displaced, lost, pushed out of, and pushed into ghettos and squatter camps. I consciously refer to 'squatter camps' instead of the more correct term 'informal settlements' because, in my opinion, one cannot take away the squalor of such settlements by using neat and politically correct language. Meanwhile, luxurious security estates are built next to or close by such settlements. Often the highways and provincial roads crisscrossing Gauteng lead a motorist past informal settlements and wealthy housing estates, often quite close to each other. An squatter camp like Diepsloot, towards the west of the R511, is in the process of being 'formalised'. However, the poverty and human decay in the community is so devastating that five children were killed and found dead over a period of five months, from September 2013 to February 2014 (eNCA 19 October 2013; Nzimande 2013;).

When one drives on the R511, one passes the luxury security estate, Dairnfern. A commercial and entertainment hub is positioned just a few kilometres further, on the crossing of Beyers Naude and Witkoppen Road, where Monte Casino offers fun-seekers a place to gamble, stay in a luxury hotel, shop, eat at sumptuous restaurants, and watch shows in stateof-the-art theatres - and simply to forget about the tensions and decay of the South African society. Indeed, the consumerist and capitalist lifestyle and expansion of the city is so greedy and voracious that the city not only seems to hide away and forget its poor, but even to swallow and devour them. Then, the horrors are forgotten as the fast-paced life of a rampantly capitalist city continues. These are the movements and spatial patterns of Johannesburg, a city that Martin Murray (2011) in the title of his book aptly calls City of extremes.

These are the horrors and the extremes of Gauteng, the province which is the economic powerhouse of post-1994 democratic South Africa. Whereas the Reconstruction and Development Policy, the document that constituted the core of the Election Manifesto of the African National Congress (ANC) in the first democratic elections in 1994, upheld the ideals of poverty eradication and the redistribution of wealth, social cohesion through community-centred political and economic decision-making and consultation, the implementation of this Policy soon failed. This was as a result of pressure from investors and members of government to become 'globally competitive', business-orientated and to privatise services and infrastructure development projects. Neo-liberalist capitalist policies and practices took over. The strong focus on bottom-up community participation and social reconstruction dissipated. In my opinion, this meant the loss of a huge opportunity to build communities and strengthen the development of those people who were dehumanised by apartheid. Power was taken away from the people and handed over on a platter, made of the gold produced in Gauteng, to powerful international investors and top-down policy makers and a powerful government. What followed, in Gauteng's case, with regard to infrastructure development and the delivery of basic services, was a story with its highs and lows. If, in the early years of democracy, these developments were rolled out too slowly and at high costs for the poor, it can at least be said that Gauteng is today the province where the most has been done in providing housing and services to poor communities. Some housing developments for poor to middle class households are quite innovative and impressive, such as the work of the Johannesburg Housing Company and the development of Cosmo City and areas around Olievenhoutbosch and on the southern side of the N14. This, however, does not mean that the power was given back to the people. Service deliveries in local municipalities and poor communities often became unreliable and dysfunctional. Water provision became interrupted, and sewerage problems and the heaping of garbage on street corners created health and environmental hazards. Service delivery protests started to erupt. Research conducted at the University of Johannesburg reported that most community protests started peacefully, but became disruptive when community's peaceful efforts to engage with the powers-that-be on local government and even national government level such as local councils, imbizo's and even the president's hotline and the public protector became exhausted and came to nothing. A lack of political representation of communities, government's and officials' unresponsiveness to the grievances of communities and corruption and unsatisfactory municipal administration also resulted in protests. Anger and frustration is at the heart of these ongoing protests and the high level of unemployment among the youth is a big factor (Grant 2014). This whole history of how the government's macro-economic policies impacted on either the inclusion or the exclusion - or displacement - of the poor, is often tragic. This displacement affects the presence or absence of the poor in the public space. Despite the good that has been done thus far, the new government has not succeeded in overcoming the horrors of Edge City and its impact on the poor.

I would like to move forward and focus on the physical spatial dimension of displacement. Garreau (1988:52) speaks about Edge City in relation to the development of huge shopping malls and security estates, where there is very little truly 'public' space and community between people of all walks of life. This is very true of the divided cities in Gauteng. Indeed, Garreau's 'Edge Cities' are, in Gauteng's case, also 'Extreme Cities'. 
People stream to shopping malls to consume and for the pleasure of just being between all the brightly-lit shops and the latest fashions. People are strangers to each other as they are there, not for community, but for consumption. It can no longer be compared to old-style public squares, or market places where trading of goods takes place, but which also allows people to meet and to discuss the issues of the day. Are perhaps the taxi ranks and the downtown areas of cities such as Marabastad in Pretoria closer to a true communal public space than the fashionable malls to which people stream? If one goes to Menlyn shopping mall in Tshwane one will also notice other features of Edge City which are typically South African: one can only reach Menlyn by car and by parking in parkades filled with petrol fumes. It is not accessible to pedestrians or to people who use taxi's that need to park outside the centre's parkade due to the way in which we know taxi's function - dropping people and hurrying away to fill up with the next load of passengers. So taxi users have to cross busy and dangerous streets to reach the mall.

Edge City is also Fortress City. Mike Davis (1998:224) remarked that the fastest growing type of 'community' in the United States of America (USA) is the gated and securityfenced community. This is not only the case in the USA. Security villages, some more luxurious, such as Mooikloof to the east of Tshwane and others catering for upper middle class or middle class owners, are becoming the newest form of urban settlement in Gauteng. Of course, one understands that the crime rate in South Africa often urges people to adopt these lifestyle choices. However, crime is not only a problem of, on the one hand, wealthy people who have to flee to security villages, and on the other hand, of brutal and unscrupulous, mostly black, criminals. Crime is a South African problem with roots in our past but also in the inequalities of our present society. Communities who regard themselves as part of the greater South African society, and who choose to come out of their isolation and to enter the public space, need to find holistic ways of dealing with crime and other social problems. Those who are frustrated by not reaching these aspirations are as much part of our society as those of us who are more privileged - but we all are part of an unsustainable socio-economic order which is not able to carry us all and which is destroying nature.

At the same time it is those in power who determine economic policy: the government departments and officials on various levels who have to implement the policies, the rich companies and producers of consumer goods, the wealthy and the middle class who consume the most, and the security companies who need to protect the privileged consumer habits and comfortable lifestyles, who have the most power to keep the poor out of Edge City and on the wrong side of the City of Extremes. Power, wealth, and consumerism - these are the push factors which keep the poor displaced, on the wrong side of Edge City. At the same time, these are the powerful factors which pull many poor people, including rural people, towards Edge City, despite the cruelty of its sharp edges and divides.
If one goes to the poorest communities and the squatter camps, one finds people who struggle to survive. Often streets are filled with garbage and dirty water. The spaces, in which the poor live out their lives, whether they are men, women or children, are often neglected and polluted. Because the poor do not have sufficient access to the basic commodities: to proper health care and good schools, wellfunctioning public services and accessible decision-making processes, they feel apathetic and do not care for public spaces as something of which they have ownership. Or they resort to social organisation and mobilisation, which are authentic expressions of their voices and frustrations, but may still be destructive towards themselves and their communities. As I have already demonstrated, service delivery protests have become a common phenomenon on the outskirts of Edge City (Grant 2014). Yet, if one goes inside the yards of squatter houses and low income houses, one may find private spaces that are generally neat and reflect a sense of personal pride, innovation and self-reliance. Rich neighbourhoods are generally cleaner and better cared for and public services are more efficient. However, it is not the rich who clean up: it is the poor whose tasks it is to clean the spaces - the houses and the streets - of the rich. Most often it is women who have to take care of the domestic cleanliness in the private spaces of the rich, and who then have to go home to take care of their own private spaces and to care for their own families.

I now move on to focus on what I will describe as both the spatial and the social displacement of people - especially the youth, women and children - in Edge City. While there is an unemployment rate of plus minus $30 \%$ in South Africa, the expectations for any form of employment among the youth are even lower. In the third quarter of $2013,34 \%$ of young South Africans in the age group 15-24 years of age could not find a job. In Gauteng, 31.1\% of the youth are unemployed. These rates of youth unemployment are among the worst in the world. It is difficult to go into the semantics of what the term 'unemployment' means in this article, but, for the youth, we have to conclude that we cannot only work with the 'conservative' definition of unemployment (namely, a reference to those who are actively seeking for work). In terms of the conservative definition, the Gauteng rate of unemployment among the youth is still reasonable (Statistics SA 2013b). However, if one uses a more comprehensive definition of unemployment (namely, a reference to those who are seeking for work in both the formal and informal industry as well as those who are underemployed or who have completely given up on searching for a job), then unemployment among the youth in the whole of South Africa becomes alarming. According to the Quarterly Labour Force Survey for Quarter 3 of 2013 (Statistics SA 2013a), the NEET rate (the number of unemployed youth and youth not in the labour force who are in education and training) among the age bracket from 15 to 24 years was 31.4\%. According to the 2014 World Economic Forum Global Risk report, South Africa has the third highest youth unemployment rate in the world, after Greece and Spain (eNCA 20 January 2014). In such conditions where the youth do not have sufficient power or opportunities 
to get out of conditions of poverty and squalor, whilst they are also exposed to the consumer values of Edge City through the media and the market and are frustrated by their inability to gain access to Edge City, they often end up in crime, on the streets and in drug abuse. Or they take part in service delivery protests - another important reason for which is unemployment and frustration among the youth (Grant 2014).

Often men who have to work as labourers, or who are unemployed return home and take out their frustration on their women. Warped cultural roles for men and women, violence against women and children are often related to conditions of extreme poverty and squalor. Women and children are the first to be affected by the waste and the fallout of Edge City. For example: between September 2013 and February 2014, five babies and toddlers were found murdered in Diepsloot. In the case of one of the murdered children in Diepsloot, the mother of the baby found dead and mutilated in the mother's shack was accused in the Pretoria Magistrate's Court, on the 26th November 2013, of being guilty of neglect, abandonment and murder (Madia 2013).

The mother's name is Nokuthula Gumede. Nokuthula means 'the one who comforts and brings peace'. This mother was no longer a bringer of comfort. She and her baby were alternatively the perpetrator and victim of neglect. Or was the mother also the victim of the neglect of specifically vulnerable women in Edge City? Is one of the contributing factors to this tragedy a society which marginalises and neglects women and children who live in the squalid conditions of a squatter camp, within close proximity of wealth and consumerism?

\section{An ecofeminist analysis of urban displacement}

Central to this article is the alternative vision of reality that motivates and directs ecofeminist theologians when they engage in action for change in an anthropocentric world order which, to a large extent, disregard the ecological nature of this reality - at the peril of the whole planet (Eaton 2003:24-35). Ecofeminist theology contests those understandings of reality which are determined by an understanding of a hierarchical ordering of God, spirit, man, woman and nature as in classical Platonic thought, which was so foundational to Western thought and Christian theology. Neither do they perpetuate the mechanistic view of nature, which came out of Newtonian science (Ruether 1992:240-53). In contrast to hierarchical and patriarchal views, ecofeminist theologians regard reality as evolutionary, ecological and processorientated. They find the creative and redemptive reality of God panentheistically, within and around these alwaysemerging processes of life on earth and of the cosmos (Christ 2003:230-36). This ecological and process-orientated view of reality recognises complexity, diversity and holism in the systems of life, but contests any 'power over' hierarchical and patriarchal ordering of reality. Within the web of life, the realities of life and death play out, but ultimately, life is nurtured through processes of birth, care and evolvement and within the safety net of interdependence. Through dynamic interdependence, the whole earth system flourishes. Ecofeminist theologians understand this reality from within their specific 'standpoint' and experience thereof. When they grapple with those powers which distort the interdependent nature of reality and which misuse power as 'power over' and not as 'power with', they do it from their specific placement within society and ecology as embodied creatures, who are, themselves, vulnerable care-givers to life (Van Schalkwyk 2008: 19-22). With this ecological understanding of reality in mind, the relevance of ecofeminism and ecofeminist theology in an analysis of urban systems hopefully becomes clear.

It brings a sharpness of analysis to the discussion of the displacement of nature and people through capitalist-driven urbanisation, which is in stark contrast to its own ecological world view. It makes the connections between the oppression of women, children and marginalised people, political and economic inequality and abuse of power, the (lack of) care within a family or within a community, and the destruction of nature. As such, it assists ecofeminist theologians and other practitioners of liberation theologies in urban contexts, to be equipped by this analysis, so as to practice an ethics of radical care for the most vulnerable members of urban society with a specific focus on women and children. Ecofeminism grapples with the unequal gender roles for men and women as it forms part of the power dynamics in urban society; as these dynamics relate to the oppression of those who are at the bottom of the patriarchal capitalist hierarchy in an urban society. The link is made between the oppression of the most vulnerable groups in society and the destruction of the ecology by the same patriarchal capitalist forces (Eaton 2003:23-37; Ruether 2003:vii-xi).

In this article, I have already pointed out how the care-lessness of those in positions of hierarchical and patriarchal political and economic power has often resulted in the destruction of waterways, the pollution of water, sewerage problems, the disruption of water and electricity services, and so on. The impact of these socio-ecological problems are mostly felt by female caretakers of households, who have to improvise to find water or to save water, to find other forms of heat and light so as to prepare meals, clean their households, and provide comfortable living conditions for their families; and by children and the youth who have to grow up in unhealthy and polluted communities and environments without the amenities which will assist them in their development and without an experience of the healing power and the freedom of nature.

Perhaps the most eminent ecofeminist critic of the prevailing world order is Vandana Shiva (1988:1-13). She fundamentally questions the Western progress-driven model of development as the only valid model for the world to follow. She refers to this model as maldevelopment, as a continuation of the process of colonisation, and extension of the project of wealth creation in modern western patriarchy's economic vision, which is based on the exclusion and exploitation of women, non-Western cultures and nature. The alternative development think-tank, DAWN (Development 
with Women for a New Era) agrees with Shiva when they assert that, as seen from the perspective of women of the South, global economic processes are the major contributors to worldwide environmental degradation as these impact on women and their livelihoods. Overconsumption and the emission of greenhouse gases in the North, but also in 'emerging markets' by countries such as South Africa, India and China, are some of the major reasons for the growing burden on the environment and on the poor in the South (Sen and Grown 1987:78-96). These global processes are often repeated by the dynamics between rich and poor, powerful and powerless within a particular society; and how these dynamics often play out on the ground, or at city- and community- level. We have seen that this often happens at the cost of the most poor and vulnerable: men, women and children in marginalised situations. However, it also happens at the cost of nature, which is hidden and silent, or simply the 'ground' on which these dynamics play out. Ecofeminist theorists argue that these top-down power dynamics need to be turned around so that an ethics of care can be implemented by community members and decision-makers who represent and answer to the most marginalised and the poorest of the poor, so as to take responsibility for caring and just human communities. Such communities consciously form part of, and are dependent on, the larger ecological systems of the earth (Cuomo 1996:42-51; Warren \& Cheney 1996:244-257). Here, care is no longer domesticised within a 'feminine' zone of care-giving, but becomes care - by men and women - of the most vulnerable individuals and spheres of society. This is the 'care that does justice', a politicised understanding of actions of care at the level of communities and ecosystems that are the most affected by the oppressive and destructive forces within an urban society. It relates the influence of socio-political factors on people's lives to the impact of these same factors on the ecology, on which human beings are dependent for their livelihoods. The 'care that does justice' is not always softly-spoken and friendly. It negotiates with people and powers to find long-term solutions to problems. It also entails persistent engagement, tenacity and sometimes vociferous critique in finding solutions for a systemic problem, while taking along people who are affected by problems, in the search for a solution. When necessary, an ethics of care requires outrage and a strong prophetic voice in the public arena.

An example of such a 'caregiver' is Ms Mariette Liefferink, the Chief Executive Officer of the Federation for a Sustainable Environment (FSA), who was one of the first people who investigated the impact of acid mine water drainage on people, livestock and agricultural land adjacent to tailings dams or polluted waterways, and persistently brought this to the attention of the media and the public despite scientific disagreement on the matter and opposition from various 'stakeholders'. She expresses the focus of the FSA as follow: 'We focus on the empowerment of disempowered communities so they can have a voice regarding environmental impacts' (Rawoot n.d.). Another vociferous 'caregiver' is Tshepo Khumbane, who lives on a plot in the northern peri-urban part of Tshwane, and who mobilised thousands of rural women in rural Limpopo and Lesotho into what became the Water for Food movement. In my interview with her (Van Schalkwyk 2008:15), she raged about government policies which do not really assist poor people, the depletion of the natural environment, the depletion of natural resources for people's subsistence and the destruction of traditional earth-caring traditional values. In my interaction with her, she also raged about the Lesotho Highland Water Scheme which did not bring water to those people who needed the bounty of Lesotho's water resources the most, namely, the rural subsistence farmers in Lesotho, of whom most are women. Lastly, a beloved caregiver in the mid-city of Tshwane is Wilna de Beer, the Director of the Tshwane Leadership Foundation (TLF). TLF is well-known for its solidarity with the Tshwane Homelessness Forum and its work to promote the interests of the thousands of homeless people of Tshwane. This often requires tough negotiations with the Tshwane Metro Council and strong opposition to their callous threats to evict hundreds of people from the Schubart Street Shelter for the Homeless, or their eviction of people from crumbling blocks of municipal flats without first finding alternative accommodation. She also founded the Lerato House for Girls in Crisis and Potters' House for Women in Crisis (Tshwane Leadership Foundation [TLF] n.d.), two projects which helped many girls and women to escape from abusive situations and to make a new start in life as empowered women.

\section{How does ecofeminist theology contribute to the restoration of God's oikos and the realisation of the scope of the missio Dei in the city?}

This brings me to the most crucial questions - which are truly missiological - in this article: How does ecofeminist theology assist urban theologians to understand the scope of the missio Dei and God's work of creation, salvation and restoration in the city? And how does ecofeminist theology contribute to the shared public space of urban theology, and urban mission, in the city? How, in a missiology of space, does the presence of God become manifest in urban spaces - also through the work of Christian urban practitioners and people with some conscience and vision who work for a better, more liveable and caring [eco-]city?

The ecofeminist theologian Sallie McFague (1993:137, 160-161) speaks of the sacramental presence of the cosmic Christ within and around the earth and the cosmos, and the actions of God through Christ in creation and recreation, which inspire us and enable us to be part of Christ's work in the world. As such, creation - and this includes the human creation of cities - is the scope and the space in which creation and salvation takes place. God is present in all the spaces and places of creation as well as in human civilisation as manifested in cities, despite human neglect and injustice. 
McFague (1993:198) then goes on to explore the theme of hope in relation to the Christian doctrine of the eschaton: eschatology is not a concern with the afterlife, but is the breaking through of new possibilities, of hope for creation, a vision of a different present based upon a new future. In this eschatological vision, salvation or the good life for all means first and foremost that the basic physical needs of the earth's creatures and systems have to be met. We are all bodies who need the basics of food, clean air and water, shelter and space, community, care, and so forth, to live. In the Christic reading of the new creation, the vulnerable and the marginalised are now included in a community of abundant life. Life abundant means abundance for all living beings, and not only for a minority of rich and middle-class people. It implies limitations and sacrifice for human beings of conscience. It therefore involves a radically different view of abundance than in the consumer society. It involves re-imagining the good life in just and sustainable ways so that the greater community of life can live in abundance (McFague 2000:xii).

\section{The 'Yes' and 'No' and 'Crying out loud' of an ecofeminist focus on urban mission}

Let me explore some practical initiatives and endeavours to bring about such abundance of life for city dwellers and urban ecology in Gauteng. In a post-apartheid South Africa, these initiatives are brought about by the democratic government on national, provincial and local government level, as well as civic organisations and movements - and, very important, in Christian urban mission, faith-based organisations focused on the urban context. A true understanding of the missio $\mathrm{Dei}$ is positive towards the possibilities and initiatives that are implemented by 'secular', state and non-governmental agencies. As in the tradition of liberation theologies, one may recognise the Spirit at work in social movements or even in a new democratic government, for that matter, if these agents are bringing about positive urban renewal. The city, as we have seen before, is a place of civitas, human endeavour, creativity and vibrant cultural happenings, and 'secular' and state organisations are part of these happenings. In the South African society, cities are vibrant spaces in which life abundant for people and for nature is sought and found within a sustainable paradigm of urban development.

David Bosch (1991:10-11) speaks about the "'Yes' of God's affirmation of creation and civilisation through the missio Dei as there is continuity between the Reign of God, the mission of the Christian community, and justice, peace and wholeness in creation and society. Still, mission is also God's 'No' to the world as Christian urban practitioners are not secular to the point that they do not stand back and look critically at the world in the light of the Gospel. Where there is wrong, or where public role players speak smoothly about sophisticated plans for urban transformation but do not really serve those who are the most vulnerable and marginalised in the city, there Christian urban practitioners have to be vociferous in their critique of the actions of public servants and tenacious in their endeavours to engage, on a practical level, with public servants, government, legal agents and community organisations to find alternatives for those inhuman situations which government agents do not solve or have even brought about and which affect the lives of the vulnerable. Sometimes public opposition and protests may even be necessary.

The Executive Mayor of Johannesburg, Councillor Parks Tau (2014), calls Johannesburg a 'city at work' in his State of the City 2014 Speech. He speaks of the 'corridors of freedom', referring to the Rea Vaya transport system which is already implemented; spatial planning for new mixed income housing developments such as Cosmo City, also already completed; and the releasing of land for new business opportunities, specifically for small and medium businesses through which the City of Johannesburg is starting to bring about a comprehensive transformation of apartheid spatial city planning. He speaks of the housing initiatives, successful health care initiatives and social packages for the indigent, social development programmes and urban agriculture initiatives which will make Johannesburg a more caring city. He also mentions the initiatives to run a city-wide greenhouse-gas inventory so as to plan for smarter energy use for the future, such as implementing mixed energy-resources; programmes to install solar water geysers in poor communities such as Alexandria (already being implemented) and to promote food gardening in such communities, et cetera. Johannesburg also recently hosted the C40 Cities for Climate Change Summit in February 2014. Yet, as fast as new housing developments for poor and lower middle class people are built in areas such as Olievenhoutbosch and Cosmo City, private developers build more and more walled-in, luxurious, security estates and new business developments. In the process, the precious Bankenveld and grasslands ecosystems are destroyed without much consideration for the protection of some of the more sensitive and beautiful natural areas. The rampant growth of the City of Extremes seems to take place at a pace with which even the progressive Executive Mayor and his Council cannot keep up.

The basic critique of an ecofeminist voice to the Mayor's speech is to test whether these caring, participatory democratic plans for a city actually do exist on the ground and in communities such as Diepsloot. We may ask where the State and Council intensive social and clinic services, social and youth workers and nurses are, who should be working on community level, in such a volatile community as Diepsloot, to pro-actively work for the protection of mothers' children? Where is the care that the Mayor is talking about? How could the City of Johannesburg and every civil and church community and citizen in Diepsloot have allowed five children to be murdered in five months? Where were the pro-active and follow-up services which should have dealt with the root causes of these tragic happenings? Where are the programmes to guide the youth of Diepsloot through the traps and the temptations of life in a disintegrating community at the edge of the luxury estates like Diarnfern; the temptations of consumer paradises 
of Monte Casino and Fourways, so that they emerge on the other side as enthusiastic youngsters who grab at the positive opportunities of life, instead of becoming apathetic and involving themselves in crime and drug abuse?

The greater city of Tshwane, probably, has the biggest challenges regarding spatial reform of apartheid urban design, with townships like Shoshanguve, GaRankuwa, Mabopane, Hammanskraal and Winterveld to its north, areas that are the 'left-overs' of the old Bantustans and now have to be dealt with by the City Council of Greater Tshwane; together with the great discrepancy in wealth and service delivery between the previously white areas of Pretoria and Centurion and these 'Bantustan' townships. The improvement in the delivery of infrastructure for all these areas is still a major task of the City Council. The regeneration and upkeep of the inner city through the development of state-of-the-art government buildings and the development of the Times Square around the Tshwane Theatre, among others, is exciting. Youth employment and the fight against drug abuse is a major challenge in the city and some progress is made in this regard. Yet, human trafficking, prostitution and the infiltration of drug syndicates into the mid-city area seem to be uncontrollable. There is also progress in the provision of housing and also title deeds for those who live in informal housing. Yet, Tshwane's population of homeless people is large, especially in the mid-city. The City Council recently dealt harshly with those homeless people who were living in the Council's shelter for the homeless when it gave the 600 people living there two days' notice to evict the shelter, so that it could be renovated. It also has a bad record on dealing with the residents of the former municipal flats, Schubart Park and Kruger Park when these people were evicted without being given alternative shelter. The city is still working towards greater renewable energy services and more effective recycling, while the beautiful green areas, especially the Magaliesberg ridges, are not sufficiently taken care of. Yet, the Mayor (Ramokgopa 2014) has spelt out his vision of a sustainable, liveable and vibrant city where social, ecological, economic and spatial agendas will be integrated.

How possible is this? Again, the private developers are beating the City Council and its vision of an integrated city by rushing to build security estate after security estate in the east of the city, whilst the squatter camps in the east are growing at just as fast a pace as the predominantly white security estates. Those who are dependent on wealthy white people for employment as domestic workers, gardeners, and other occupations can reach their employers' residences without travelling far distances in taxis and buses. The irony of the situation cannot go unnoticed.

It is in this City of Extremes that Christian faith communities, faith-based organisations and related social networks in Tshwane carry a large responsibility to bring the 'Yes' and the 'No' of the missio Dei out into the open. These different movements are doing sterling work in recognising what good the provincial and local governments in cities are doing for the poor, while yet testing this from a stance of serving solidarity with the poorest of the poor. The example of Tshwane Homelessness Forum (THF) comes first to mind here. With the recent evictions of people from the municipal shelter for the homeless, it was the THF, together with their partner organisation, the TLF, which stood up against the Council workers who were not interested in finding common ground with THF and TLF, to find a solution to the crisis that the homeless were facing. In close cooperation with the THF, a lawyer from Lawyers for Human Rights had to write a letter to the Council, instructing them to find decent temporary shelter for the residents of the shelter, before renovating it. Otherwise, Lawyers for Human Rights would take the matter to court. At the time of writing, THF are still waiting for a response from the Council (Monama 2014).

The prophetic and caring role of faith-based organisations like TLF, Yeast City Housing and PEN Action (PEN is the abbreviation for Participate, Empower and Navigate) in the city of Tshwane and specifically in the Tshwane mid-City cannot be overestimated, despite the financial problems that these faith-based organisations face. They are the ones who, to a large extent, realise the values of an ecofeminist ethics of care, even if they would not necessarily use that term. Together with other non-governmental organisations (NGOs) as well as the social workers of the Department of Social Development, they serve women and children in crisis and help them to recover their lives and re-enter society as empowered people. They embody the prophetic and caring message of Jesus Christ the great Servant (or Diakonos). A further sharpening of these organisations' ability to analyse the impact of hierarchical and patriarchal political and economic forces on vulnerable communities and on the ecology may assist them to render more holistic care and to implement more comprehensive projects and programmes which will address these powers and their consequences for the cities in which they serve, but also in the larger South African society with its high dependence on dirty energy and mining, which again impacts on the ecology of the whole sub-continent.

This vision of life abundant for all living beings - especially for the most vulnerable - is a here-and-now vision. Much of it can be realised, but much is still a far way off. What I do want to propose at the end of this article is that Christian and other 'sacred activists' start freeing up the Edge City of the capitalist order by claiming spaces in the city as spaces of spirituality, justice, community and inclusion. By doing so, one starts, step by step, to liberate the city from displacement and amnesia.

\section{In conclusion}

\section{Urban mission as a liturgy of reclaiming sacred space and place}

Reclaiming urban spaces as sacred are symbolic actions of discovering and recovering the green city - a dwelling for the community of humanity, nature and God within the greater oikos - not only through the liturgical entering into sacred space, but also through the renewed action which 
flows from the liturgical participation in meeting the God of the civitas Dei in these sacred spaces. This starting point for urban activism based in a sacramental understanding of space (where space reminds us of the presence of God in the oikos) is one important way to renew our spirituality of life and struggle for life as we engage ourselves in what are often very challenging and demanding encounters with the realities and the forces of the city. It always brings us back to our belief that it is God's love which carries the world and the continuing process of creation, and which also carries our actions in the world. This love is literally what makes life on earth viable and what will hold us and the earth together in a search for sustainability.

I would like to give this liturgical connection between sacred spaces, the reclaiming of sacred space and Christian urban activism a name: it is a missiology of space.

According to the Gospels of Matthew (ch. 21 vs. 1-17), Jesus moved from the Mount of Olives and the humble village of Bethany to worship at the temple. He became angry when he saw how people were abusing the temple's courtyard for buying and selling. He drove out the people, and overturned the tables of the money-changers and the benches of those selling doves. He proclaimed that the money-lenders and traders had made the house of God a 'den of robbers'. Then the blind and the lame came to him and he healed them. The children started shouting 'Hosanna to the Son of David'. After demonstrating his righteous anger and driving out the unjust, Jesus re-consecrated the court yard of the Temple, that space of the temple which was accessible not only to the priests but to the ordinary people, by healing the blind and the lame and by listening to the children's joyous recognition of his miracles. The (re)-sacralisation of urban space, in my mind, should also be a sacred liturgical space of (natural) beauty, worship and meditation. In the case of Jesus it was a place of natural beauty and significance, the Mount of Olives. From such a place, urban practitioners can literally and metaphorically go on a pilgrimage to specific urban spaces to (re-)establish the presence of God through their activism, prophecy and care, and in a way that contributes to the restoration of human community and natural ecology in the city. Starting from a place of beauty, worship and liturgy and then intentionally undertaking a pilgrimage to places of innovation, prophecy and justice is therefore central in the theology and practical work of urban mission.

It may be possible that these places of natural beauty and worship are not Christian churches or centres as such. For me, attending a conference on 'Christian faith and the earth' in August 2009 at the Sustainability Institute near Stellenbosch, was inspirational - and spiritual - because the Institute is so strongly focused on integrating ecological and human harmony. It is intentionally designed as an example of a liveable, ecologically designed urban system. This includes, among others, sustainable agriculture, the building of a housing development which brings all classes and races of people together in community and harmony with nature, influencing sustainable and liveable urban development in the Cape Peninsula and elsewhere, bringing together knowledgeable people and students who want to find practical ways of spreading the 'message' of sustainability, and much more (Swilling \& Annecke 2012:288-308). In a sense, the group of Christian theologians who met there had a great deal to learn and experience at the Sustainability Institute about how ecological and human harmony can be lived and realised, more than what they could bring to the Institute. In this sense, it was a sacred space from where we could go, inspired and renewed, to the places and spaces where we had to go and realise sustainability as ecological and human harmony.

In this manner, and inspired by the Sustainability Institute, I would like to draw the links between a space where so many liturgical journeys of urban mission in, Tshwane have started, namely, the sacred space of the Jubilee Centre of Tshwane Leadership Foundation. On the opposite side of Burger's Park Street is the urban green space of Burger's Park with its huge wild fig trees, which are more than a century old. Let us move from here to Kruger Square at the heart of Tshwane Central Business District, which is surrounded by mostly government buildings and the 'Ou Raadsaal' (the Old Hall of Justice) where the City Council is based. Coming from the community of radical equality which exists around the Jubilee Centre, the workers of TLF approach the Old Hall of Justice, with this spirit of prophecy and participatory democracy. When they enter the Hall and negotiate with the Councillors and council officials, they interact with what should ideally be the spirit of participatory democracy in the Hall, and in a way which realises this spirit and thereby sanctifies this space of government. From here, they may move to the Monument to the Unknown Child in the neighbourhood of Salvokop, slightly to the southwest of Church Square, where they acknowledge the children - known and unknown - for whose present realities and futures they work. Then they move on, up the hill, to where the magnificent structures of Freedom Park harmonise with the beautiful natural location of Salvokop, next to the hill where the Voortrekker Monument is situated, to bring together South African history and ecology in a sacred place of reconciliation.

\section{Acknowledgements Competing interests}

The author declares that she has no financial or personal relationship(s) that may have inappropriately influenced her in writing this article.

\section{References}

Bond, P., 2002, Unsustainable South Africa: Environment, development and social protest, University of Natal Press, Pietermaritzburg.

Bosch, D. J., 1991, Transforming mission, Orbis Books, Maryknoll, NY.

Bowie, F. \& Davies, O., 1990, Hildegard of Bingen: An anthology, SPCK, London.

Burck, J., Marten, F. \& Bals, C, 2014, 'The climate change Performance Index: Results 2014 ', in Germanwatch, viewed 05 June 2014, from https://germanwatch.org /en/download/8599.pdf

Christ, C.P., 2003, She who changes: Re-imagining the Divine in the world, Palgrave Macmillan, New York, NY. 
Cobb, J., 2007, A Christian, natural theology, Westminster John Knox Press, Louisville, KY.

Cock, J., 2008, The war against ourselves: Nature, power and justice, Wits University Press, Johannesburg.

Coetzee, H., (compiler) 2004, 'An assessment of sources, pathways, mechanisms and risks of current and potential pollution of water and sediments in gold-mining areas of the Wonderfonteinspruit catchment', Water Research Council Report No $1214 / 1 / 06$, Pretoria, 266p.

Coleman, M.A., Howell, N. R \& Tallon Russell, H. (eds.), 2011, Creating women's theology: A movement engaging process thought, Pickwick Publications, Eugene, OR.

Conradie, E.M., 2011, 'Missiology and ecology: An assessment of the current state of the debate', A keynote address delivered at the conference of the Australian Association for Mission Studies (AAMS), Sydney, 22-25 September viewed 24 July 2014, from http://www.missionstudies.org.au/files/aams/ ConradieKeynote2Ecology.pdf

Cuomo, C., 1996, 'Toward thoughtful ecofeminist activism', in K. Warren (ed.), Ecological feminist philosophies, pp. 42-51, Indiana University Press, Indianapolis, IN

Davis, M., 1998, City of quartz, Pimlico, London.

'Diepsloot infants laid to rest', eNCA, 19 October 2013, viewed 04 June 2014, from http://www.enca.com/south-africa/diepsloot-infants-laid-to-rest

Dlamini, P., 2014, 'Johannesburg plans transport link between Diepsloot and Randburg', Business Day LIVE, viewed 24 July 2014, from http://www.bdlive. co.za/national/2014/02/19/johannesburg-plans-transport-link-betweendiepsloot-and-randburg

Eaton, H., 2003, 'Can ecofeminism withstand corporate globalization?', in H. Eaton \& L.A. Lorentzen (ed.), Ecofeminism and globalization: Exploring culture, context, and religion, pp. 23-37, Rowman \& Littlefield Publishers, Oxford.

Eaton, H. \& Lorentzen, L.A., 2003, Ecofeminism and globalization: Exploring culture, context, and religion, Rowman \& Littlefield Publishers, Oxford.

Garreau, J., 1988, Edge city, Anchor Doubleday, New York, NY.

Gorringe, T.J., 2002, A theology of the built environment: Justice, empowerment, redemption, Cambridge University Press, Cambridge.

Grant, L., 2014, 'Research shows sharp increase in service delivery protests', Mail \& Guardian, viewed 21 July 2014, from http://mg.co.za/article/2014-02-12 research-shows-sharp-increase-in-service-delivery-protests

Howell, N.R., 2011, 'Women, Whitehead and Hartshorne: What characterizes processrelational women's worldviews', in M.A. Coleman, N.R. Howell \& H. Tallon Russell (eds.), Creating women's theology: A movement engaging process thought, $\mathrm{pp}$. 20-28, Pickwick Publications, Eugene, OR.

'Infant found dead in Diepsloot', eNCA, 19 October 2013, viewed 04 June 2014, from http://www.enca.com/south-africa/infant-found-dead-diepsloot

Kardas-Nelson, M., 2010, 'Mpumalanga's not-so-clean coal', Mail \& Guardian, viewed 03 June 2014, from http://mg.co.za/article/2010-11-29-mpumalangasnotsoclean-coal

Madia, M., 2013, 'Diepsloot mother in court', in Powerfm, viewed 04 June 2014, from http://www.powerfm.co.za/general-news/diepsloot-mother-in-court/

McCarthy, T.S., 2011, 'The impact of acid mine drainage in South Africa', South African Journal of Science 107(5/6), Art. \#712, 7 pages. http://dx.doi.org/10.4012/sajs. v107i5/6.712

McFague, S., 1993, The body of God: An ecological theology, Fortress Press, Minneapolis, MN.

McFague, S., 2000, Life abundant: Rethinking theology and economy for a planet in peril, Fortress Press, Minneapolis, MN.

Mesle, R., 1993, Process theology: A basic introduction, Chalice Press, St. Louis, MO.

Monama, T., 2014, 'Poor face eviction: Notice to resident to quit shelter a grave error - city', Pretoria News, 30 May.
Murray, M.J., 2011, City of extremes: The spatial politics of Johannesburg, Wits University Press, Johannesburg.

Nzimande, B., 2013, 'Boy's body found in Diepsloot', eNCA, viewed 04 June 2014, from http://enca.com/south-africa/childs-death-angers-residents

Primavesi, A., 2000, Sacred Gaia, Routledge, Abingdon.

Ramokgopa, K., 2014, 'State of the City Address', City of Tshwane, 03 April 2014 viewed 09 June 2014, from http://www.tshwane.gov.za/Speeches/State\%20 of\%20the \%20Capital\%20City\%20Address\%20-\%2003April\%202014\%20-\%20 FINAL\%2OVERSION.pdf

Rawoot, I., n.d., 'Mariette Liefferink', in Mail and Guardian Book of South African Women, viewed 21 July 2014, from http://bow2011.mg.co.za/profile/ marietteliefferink

Ruether, R.R., 2003, 'Foreword', in H. Eaton \& L.A. Lorentzen (eds.) Ecofeminism and globalization: Exploring culture, context, and religion, pp. vii-xi, Rowman \& Littlefield Publishers, Oxford.

Ruether, R.R., 1992, Gaia and God: An ecofeminist theology of earth healing, HarperSanFrancisco, San Francisco, CA.

'SA tops youth unemployment charts', eNCA, 20 January 2014, viewed 05 June 2014, from http://www.enca.com/money/sa-youth-unemployment-rate-among-global-worst

Sen, G. \& Grown, C. (eds.), 1987, Development, crises and alternative visions: Third world women's perspectives, Monthly Preview Press, New York, NY.

Sheldrake, P., 2001, Spaces for the sacred: Place, memory and identity, The John Hopkins University Press, Baltimore, MD.

Shiva, V., 1988, Staying alive, Zed Books, London.

Statistics South Africa, n.d., Statistics by place: Gauteng, viewed 05 June 2014, from http://beta2.statssa.gov.za/

Statistics South Africa (Stats SA), 2013a, Quarterly labour force survey, Quarter 3, 2013, viewed 05 June 2014, from http://www.statssa.gov.za/publications/ P0211/P02113

Statistics South Africa (Stats SA), 2013b, Statistics on youth unemployment, viewed 21 April 2014, from http://www.statssa.gov.za/publications/P02111/P02113

Swilling, M., \& Annecke, E., 2012, Just transitions: Explorations of sustainability in an unfair world, UCT Press, Cape Town.

Sykes, J.B., 1984, The concise Oxford dictionary, 7th edn., Oxford University Press, Oxford.

Tau, M.P., 2014, 'State of the City Address', Official website of the city of Johannesburg, 14 April 2014, viewed 09 June 2014, from http://www.joburg.org.za/index. php?option $=$ com content $\&$ view $=$ article $\& i d=9044$ : state-of-the-city-address2014-speech\&catid=88:news-update\&Itemid=266

'Toddler's body found in Diepsloot', eNCA, viewed 04 June 2014, from http://www. sabc.co.za/news/a/85c4178042f2b482972e9f895990ad13/Toddlers-body-foundin-Diepsloot-20141602

Tshwane Leadership Foundation (TLF), n.d., viewed 24 July 2014, from http://www. tlf.org.za

Tuan, Y.-F., 1977, Space and place: The perspective of experience, The University of Minneapolis Press, Minneapolis, MN.

Van Schalkwyk, A., 2008, 'Women, ecofeminist theology and sustainability in a postapartheid South Africa', Journal of Theology for Southern Africa 130(3), 6-24.

Warren, K.J. \& Cheney, J., 1996, 'Ecological feminism and ecosystem ecology', in K.J. Warren (ed.), Ecological feminist philosophies, pp. 244-259, Indiana University Press, Indianapolis, IN

Warren, K.J. (ed.), 1996, Ecological feminist philosophies, Indiana University Press, Indianapolis, IN.

WWF-SA, n.d., Coal and water futures in South Africa: A case for conserving headwaters in the Ekangala grasslands, viewed 03 June 2014, http://awsassets. wwf.org.za/downloads/coal_and_water_report_mediabackgrounder_final.pdf 